\title{
Discussion on the Popularization and Application of the Standardization of International Trade Documents
}

\author{
Zhixia He \\ The University of Haikou economics, Haikou, Hainan 571127
}

Keywords: international trade; documents; standardization; popularization and application

\begin{abstract}
With the development of the times and social progress, the promotion of international trade documents standard has gradually been familiar with and accepted by the public. However, some shortcomings still exist in the promotion of the scope of China, and some foreign trade enterprises and the higher occupation technical college also have some problems in the process of publicity and promotion. Through the investigation, the paper expounds the present problems, and put forward some reasonable suggestions and measures.
\end{abstract}

\section{Introduction}

At present, international trade documents mainly refer to the ability to use a variety of documents and documents and related certificates within the scope of international trade. In the process of market operation, we can effectively use the international trade documents to ensure that both sides of the trade can get relevant trade issues such as cargo transportation, cargo insurance, inspection and Quarantine of goods, etc. China's trade processes and documents are simplification and standardization, which can effectively reduce other costs of trade transactions and effectively promote international trade and development. Simplification of internal procedures of trade items can effectively enhance the standardization of trade documents. It is a standardized form of document format and information recording at this stage[1].

With the acceleration of information globalization in our country, the development costs and tariff costs in trade are decreasing. Some of the trade's standards and technical regulations have more and more influence on national trade. By studying the existing problems in the standardization of international trade documents, we can effectively improve the economic efficiency of China's foreign trade enterprises and promote the rapid development of China's foreign trade.

\section{The simplification of trade procedures and the standard system for international trade documents}

At this stage the international trade center is a engaged in research and development and release of facilitation and international standards on government international organization, its main purpose is to through the development of globalization as long as the standard of technical barriers to international trade are eliminated, to a certain extent promoted the establishment of the system of international trade market standard. Such a system has been widely used and promoted worldwide, ensuring the support and response of the WTO and the world customs organization to international trade associations, ICC and international standard organizations[2].

\section{Research on the application of national standards for international trade documents}

At present, the website of China Standardization Committee has some national standard announcement query functions, and some national standard directory query capabilities, and has the national standard full text online reading and national standard plan inquiry function. But if you want to know more about the details of the international trade document, you need to pay for it. In the standard of international trade documents in the promotion process, also detailed understanding of the Standardization Administration between China's various regions and provinces and some 
related administrative part of international trade documents recommended, asked whether the promotion of full, final result is not satisfactory[3].

At present, customs declaration is an important international trade document in international trade activities. Until now, the standard of declaration is not clear. In the scope of the pilot customs clearance, research and analysis of many enterprises through the customs where the customs and related problems, which can in the area of the customs declaration certification, signed the electronic agreement, without clearance paper mode and can use modern customs in range. Through the investigation and Research on the data published by the relevant websites of China's electronic ports, many countries in the world do not adopt the trade standard published by the state in international trade. Certificate of origin in some trade activities in China is an important document in international trade. It is usually handled by entry and exit inspection departments in various regions in China. However, this new trade inspection standard is still not adopted in many areas at this stage[4].

At present, China's Standardization Research Institute and the national development and Reform Commission Training Center have been promoting the international trade standardization project within the National Information Center. The nature of national development and Reform Commission Training Center and Research Institute conducted a number of public information, to a certain extent, announced the standard international trade promotion should be established and effective project, combined with other departments and project related to research and analysis, to carry out effective cooperation activities, through the dissemination and promotion of research and training of international standard trade.

After more than a year of publicity and training, our national development and Reform Commission Training Center, China Standardization Research Institute and the United Nations Industrial Development Organization held the international trade standardization Application Research Forum in Beijing. The main content is to come to participate in the meeting of people realize, effectively carry out the standard of international trade and promotion, is a very meaningful thing, and it is necessary to have the ability and what it can to a certain extent for various industries in the world and outstanding people involved. In the past few years, a number of units have recognized the promotion and application of international trade standardization, and signed a series of undertaking contracts, marking the development level and pace of China's international trade[5].

After training of relevant departments' development level of international trade, some standardized research departments and departments have trained and publicize the activity, and the exhibition conference of international trade standardization and talent development has been gradually developed in various regions of the country. And the national information center and standardized research projects have recognized the need to transfer the work center to the training center and the national quality supervision and inspection, and timely publicize and train the content. And the unit should also be changed into the national information center and the National Standardization Research Center. In the international trade standardization information office, some special measures should be set up to understand and advance the relevant knowledge. In the second half of 2013, the information application project research team of China and the international standard Mo aunt said that some of its internal need for training textbooks and handouts have written, but want to achieve satisfaction and there is a certain gap, and in various regions of the country have not started training.

Through the investigation of the current international trade documents standards of Chinese foreign trade enterprises, the survey forms are divided into the electronic version of palm survey and the single page survey of paper. First of all, in the vast majority of the respondents, more than $70 \%$ of them were blocked because of the problem of international trade documents. Most of them were customs failure due to the detention of goods at customs. Secondly, it can be seen in many of the surveyed objects that the wrong documents are decibels, packing lists, customs declarations, commercial invoices and insurance policies. Thirdly, in most of the surveyed enterprises, a lot of people think that the export documents are wrong, as long as the reason is that the content is not up to the requirements, not because the format of the documents is wrong. Fourth, first, a small number 
of respondents showed that they were using the relevant international trade documents, standards, commercial invoices and packing documents which have been developed in China, and many of them failed to use perfect and reasonable standard documents. Fifth, nearly half of the surveyed companies use national recommended transport signs in import and export contracts and other documents. A few of the respondents were not using the national standards when they used the transport marks, and most of the respondents did not use the transport marks. Finally, in view of the recommendations issued by the attack trade electronic business committee, many companies know a little about that standard, but some companies know a little about it. On the basis of international trade documents, many recommended standards in our country are very vague in the surveyed users. A lot of units have participated in the Standardization Conference and training of international trade documents in the international trade standard forum and Research Conference. Besides, at the present stage, most of the respondents can be aware that using the national standard according to the regulations can eliminate problems and reduce transaction costs, so as to effectively improve the internal economic benefits of enterprises. Therefore, most enterprises will actively understand and study the national standards of international trade documents. Some investigators also believe that it is necessary to actively establish a single service window[6].

At this stage due to higher school occupation technology of our country has opened some international trade and other related professional, including the major of international trade practice, international economic and trade professional and international business professional, these professionals will learn courses related to international trade documents. In order to know more about students' learning level of international trade documents and understand the status of China's international standards for teachers' international trade documents, a questionnaire survey was conducted among teachers in the field. First, for the simplified and standardized system of international trade procedures, many of the respondents said they would understand, but not very well. Secondly, in the summary of the research process of the national trade documents standard, some of the respondents said they could only understand one of them, which is not very comprehensive, and there are also some situations which are not known. In third, the subjects of the investigation, there is a small part of the staff said they had participated in the China international trade standardization research forum and Research Conference, most respondents said did not participate in the International Conference on standardization of trade documents and related research or Xuan Chuanpei training etc.. Fourth, when investigating the respondents, it is indicated that many commercial invoices and packing lists used by many people in the classroom do not conform to our national standards. Fifth, the transport that is basically all used by the respondents is in conformity with our national transport standards. Sixth, basically all the investigators have not used the materials related to the national trade documents to study and train. Finally, basically, all the respondents said they had a very important role in learning the international trade documents international standard and the national label, and they could create a good early environment for building a single window office.

\section{Suggestions for the popularization of the standardization of international trade documents}

First, at the present stage of China's standardization of international trade related departments and administrative departments have put forward the corresponding measures to promote international trade documents and relevant national standards, pay for access permissions and some national standards are related to international trade standard has a bad influence, is not conducive to the standard publicity and learning. Second, in China's customs activities, the use of paperless office electronic port website regularly announces the codes used in customs declarations, which can guarantee the use of excellent recommendation standards. The certificate of origin certificate authority for some export goods has not been carried out and implemented in accordance with the relevant national standards. Third, at present, China has gradually carried out some research meetings and training forums which are in line with China's standardization, which can play a good role in the standardization of international trade. But because of the late market training topics and some project work, the information management center in China can effectively change the national 
standardization training center and standardization research office, ensure that the international trade standard information project management, project of training for the market to create well prepared. Fourth, at present most of China's foreign trade enterprises in the process of operation and development, often fails due to customs clearance documents written content does not meet the requirements, but many enterprises are not aware of filling can improve the clearance rate in accordance with national standards, but also to further improve the enterprise internal staff business ability and quality documents to reduce the error rate, filling orders. In addition, if we can adopt the national standard of international trade documents, we can effectively eliminate obstacles in customs clearance and reduce expenses in transaction process, and we can take the initiative to understand the national standard of international trade documents. Fifth, China's foreign trade enterprises must focus on the national standard of international trade documents in relevant colleges and universities in the process of training relevant talents. Sixth, Chinese enterprises have not been able to understand and learn some related standardization of international trade documents for the time being. Related higher vocational schools have also gradually reduced the interpretation of international trade standards because of the lack of these capabilities. In addition, China's national standards for international trade documents should be perfected to ensure that colleges and universities can use the latest international trade documents standard textbooks.

First of all, relevant government departments in China should actively publicize and publicize the national standards of international trade documents, so as to improve the business capabilities and quality requirements of internal documents. Secondly, China's customs and commodity inspection departments should use the national standards as soon as possible to ensure that all operations within the Department can be more standardized and effective. Third, in view of some non marketable operation at present stage, the national standard government should provide free reading service that is wanted, so as to ensure that standardized work management can be applied to work and better recommend people to use. Fourth, the state should actively encourage the relevant international trade major to carry out the social services of the national standard category, so as to better promote the development of China's international trade. Fifth, we must encourage our enterprises to adopt commercial invoice and packing list according to the national standard format, so as to create favorable conditions for better implementation of China's international trade single window. Finally, China's Higher Vocational and technical schools related to international trade should be able to effectively promote the foreign trade industry and ensure the establishment and use of the national standards for international trade documents.

Conclusions

The development of standard documents in international trade promotion has become increasingly fast, the promotion within the scope of our country still exist deficiencies, and some of the foreign trade enterprise and the higher occupation colleges of technology are summarized in the publicity and promotion process also has some problems, based on the present problems and puts forward relevant survey results described suggestions and measures.

\section{References}

[1] Wang D, Jiang H. Popularization and Application of Agricultural Standardization Based on the Industrial Development Perspective__-Taking Kiwifruit Industry in Pujiang of Sichuan Province as an Example[J]. Agricultural Outlook, 2017.

[2] Gang-Rong L I, Hao W U, Gu-Xiang L I. Discussion on the standard system of digital hospital [J]. Chongqing Medical Journal, 2005.

[3] Xin C H. Discussion on Standardization of Chinese Liquor [J]. Liquor-Making Science \& Technology, 2010.

[4] Feng X, Xinzhanhong. Centralization, standardization and refination on the electronic channel of the company[C]// International Conference on Consumer Electronics, Communications and Networks. IEEE, 2012:1712-1715. 
[5] Wang G Z, Yong-Xiang M A, Kuang W G. Discussion on the Popularizing and Standardizing the Use of Crop Name in Agricultural Sci-tech Periodicals[J]. Journal of Library \& Information Sciences in Agriculture, 2010.

[6] Yuan L. On the Standardization Development Trend of Chinese Characters [J]. Yindu Journal, 2000.

Author: Zhixia He, Hunan Ningxiang province October 1979.Female, Han, lecturer, master, mainly engaged in international trade research 